\title{
CAK, the $\mathrm{p} 34^{\mathrm{cdc2}}$ activating kinase, contains a protein identical or closely related to $\mathbf{p}^{\mathrm{M} O 15}$
}

\author{
Mark J.Solomon ${ }^{3}$, J.Wade Harper ${ }^{1}$ and \\ John Shuttleworth ${ }^{2}$
}

\author{
Department of Molecular Biophysics and Biochemistry, Yale \\ University, New Haven, CT 06510, ${ }^{1}$ Verna and Marrs McLean \\ Department of Biochemistry, Baylor College of Medicine, Houston, \\ TX 77030, USA and 2Department of Anatomy, The Medical School, \\ University of Birmingham, Birmingham B15 2TT, UK \\ ${ }^{3}$ Corresponding author \\ Communicated by T.Hunt.
}

The mitotic inducer $\mathrm{p} 34^{\mathrm{cdc} 2}$ requires association with a cyclin and phosphorylation on Thr161 for its activity as a protein kinase. CAK, the p34 $^{\text {cdc2 }}$ activating kinase, was previously identified as an enzyme necessary for this activating phosphorylation. We confirm here that CAK is a protein kinase and describe its purification over 13 000-fold from Xenopus egg extracts. We further show that CAK contains a protein identical or closely related to the previously identified Xenopus MO15 gene: p40M015 copurifies with $\mathrm{CAK}$, and an antiserum to p40 ${ }^{\mathrm{MO} 15}$ specifically depletes cAK activity. CAK appears to be the only protein in Xenopus egg extracts that can activate complexes of either p34ctc2 or the closely related protein kinase, p33 $^{\mathrm{cdk} 2}$, with either cyclin A or cyclin B. The sequence similarity between $\mathrm{p40} 0^{\mathrm{MO15}}$ and $\mathrm{p34} 4^{\mathrm{cdc} 2}$, and the $\sim 200 \mathrm{kDa}$ size of CAK, suggest that p40M015 may itself be regulated by subunit association and by protein phosphorylations.

Key words: CAK/p34 $4^{\mathrm{cdc} 2} / \mathrm{p} 40^{\mathrm{MO} 15} /$ protein kinase/p33 ${ }^{\mathrm{cdk} 2}$

\section{Introduction}

A large number of cell cycle transitions are regulated biochemically by protein-protein interactions and by phosphorylations. A paradigm for these controls is the p34 ${ }^{\text {cdc2 }}$ protein kinase, whose activity is required for the $G_{2}$ to mitosis transition in all eukaryotic cells (for reviews see Nurse, 1990; Norbury and Nurse, 1992; Solomon, 1993). Monomeric $\mathrm{p} 34^{\mathrm{cdc} 2}$ is inactive and unphosphorylated; binding to a cyclin protein is required for both its activity and its phosphorylation (Solomon et al., 1990; Meijer et al., 1991; Parker et al., 1991; Solomon et al., 1992). Three major sites of phosphorylation have been identified, corresponding to Thr14, Tyr15 and Thr161 in the human p34 ${ }^{\text {cdc2 }}$ protein (Gould and Nurse, 1989; Gould et al., 1991; Krek and Nigg, 1991; Norbury et al., 1991; Solomon et al., 1992). Phosphorylation of either Thr14 or Tyr15 is inhibitory; both sites must be dephosphorylated prior to activation. Phosphorylation of Thr161, on the other hand, is absolutely required for $\mathrm{p} 34^{\text {cdc2 }}$ activation. Homologs of the weel gene product in Schizosaccharomyces pombe, genetically identified as a negative regulator of $\mathrm{p} 34^{\mathrm{cdc} 2}$, phosphorylate Tyr15 (Parker et al., 1992; Parker and
Piwnica-Worms, 1992; McGowan and Russell, 1993). Thr14 appears to be phosphorylated by a distinct protein kinase (Parker and Piwnica-Worms, 1992; McGowan and Russell, 1993). Homologs of the S.pombe cdc25 gene product dephosphorylate both Thr14 and Tyr 15 (Dunphy and Kumagai, 1991; Gautier et al., 1991; Millar et al., 1991; Strausfeld et al., 1991; Lee et al., 1992), thus activating p34 ${ }^{\mathrm{cdc} 2}$. No strong genetic candidates exist for the protein kinase that phosphorylates Thr161.

An enzymatic activity has been identified in Xenopus egg extracts (Solomon et al., 1992) and in mammalian tissue culture cell extracts (Desai et al., 1992) that causes the phosphorylation of $\mathrm{p} 34^{\mathrm{cdc} 2}$ on Thr161 in the presence of cyclin. This enzyme was termed CAK, for $\mathrm{p} 34^{\mathrm{cdc} 2}$ activating kinase, and was partially purified (Solomon et al., 1992). Phosphorylation of an apparently catalytically inactive form of Xenopus $\mathrm{p} 34^{\mathrm{cdc} 2}$ (containing a K33R mutation) by partially purified CAK suggested that CAK was a protein kinase, rather than an activator of autophosphorylation by p34 ${ }^{\text {cdc2 }}$ (Solomon et al., 1992). The CAK-induced phosphorylation of $\mathrm{p} 34^{\mathrm{cdc} 2}$ was required for its protein kinase activity, but not for its association with cyclin; moreover, Thr161 phosphorylation was not a prerequisite to dephosphorylation on Thr14 or Tyr15 (Solomon et al., 1992). The CAK-induced phosphorylation of Thr 161 occurred only in the presence of cyclin, both in a complete Xenopus egg extract and in a simplified in vitro system using more purified components (Solomon et al., 1992).

Close relatives of $\mathrm{p} 34^{\mathrm{cdc} 2}$ have been identified in a number of species and termed 'cdks', for cyclin-dependent protein kinases (Elledge and Spottswood, 1991; Paris et al., 1991; Meyerson et al., 1992); their regulation seems to follow the paradigm established by cyclin $-p 34^{\text {cdc2 }}$. For instance, $\mathrm{p} 33^{\mathrm{cdk} 2}$ can be negatively regulated by phosphorylation on Thr14 and Tyr15, and is positively regulated by phosphorylation on $\mathrm{Thr} 160$ (Gu et al., 1992). Although $\mathrm{p} 33^{\mathrm{cdk} 2}$ can be dephosphorylated by $\operatorname{cdc} 25$ (Gabrielli et al., 1992; Gu et al., 1992) and phosphorylated on Thr 160 by CAK in vitro (Connell-Crowley et al., 1993), it is not clear if these are the physiologically relevant enzymes for these processes. Just as new and diverged members of the p34 $4^{\mathrm{cdc} 2}$ and cyclin families are being discovered, it should not be surprising if more proteins related to wee1, cdc25 and CAK are found, perhaps with shared specificities. Association of cyclins A or B with p34 $4^{\text {cdc2 }}$ and p $33^{\text {cdk2 may }}$ further limit the substrate specificity of these modifying enzymes. Some of these possibilities have been examined in the present work.

We have now enriched CAK over 13000 -fold from Xenopus egg extracts, confirmed the previous suggestion that CAK is a bona fide protein kinase (Solomon et al., 1992) and shown that $\mathrm{p} 40^{\mathrm{MO} 15}$ or a very similar protein is a component of CAK. MO15 was originally cloned as part of a search for Xenopus $\mathrm{p} 34^{\mathrm{cdc} 2}$-related proteins and was 
suggested to be a negative regulator of oocyte maturation (Shuttleworth et al., 1990). We show that CAK is the main (or only) activator of both $\mathrm{p} 34^{\mathrm{cdc} 2}$ and $\mathrm{p} 33^{\mathrm{cdk} 2}$ complexed with either an A- or a B-type cyclin in Xenopus egg extracts. Two other groups have reached similar conclusions; their results are reported in the accompanying papers (Fesquet et al., 1993; Poon et al., 1993).

\section{Results}

\section{CAK is a protein kinase}

It has been suggested that $\mathrm{p} 34^{\mathrm{cdc} 2}$ may autophosphorylate on Thr161 (Nigg et al., 1991), since Thr161 aligns with an autophosphorylation site found in a number of protein kinases (Hanks et al., 1988). CAK would then be a stimulator of autophosphorylation by $\mathrm{p} 34^{\mathrm{cdc} 2}$, rather than a true protein kinase. Previous work demonstrated that CAK could phosphorylate an apparently inactive mutant of p34 ${ }^{\text {cdc2 }}$ (Solomon et al., 1992). However, since the K33R mutant used in these studies may have a low level of residual protein kinase activity ( $<\sim 5 \%$ of wild type activity), the possibility that CAK stimulated the autophosphorylation of p34 $4^{\text {cdc2 }}$ could not be excluded. The following experiments address this issue more rigorously.

CAK's ATP-binding capability was tested by determining its sensitivity to the ATP analog 5'-p-fluorosulfonylbenzoyladenosine (FSBA). All protein kinases can bind ATP, whereas a non-kinase activator might not be expected to do so. FSBA inactivates protein kinases by binding to the ATPbinding site and becoming covalently attached to an active site amino acid side chain, expected to be Lys33 in p34 $4^{\text {cdc2 }}$ (Zoller et al., 1981; Coleman, 1983). Following incubation, FSBA was inactivated and the residual CAK activity determined in a two part assay: CAK-containing samples were incubated in a kinase buffer with reticulocyte lysatetranslated Xenopus p34 cdc2 (Gautier et al., 1991; Solomon et al., 1992) and cyclin B, a bacterially expressed fusion protein containing the enzyme glutathione S-transferase attached to the N-terminus of a sea urchin B-type cyclin (Solomon et al., 1990). The degree of $\mathrm{p} 34^{\mathrm{cdc} 2}$ activation was subsequently determined in a direct protein kinase assay, using histone $\mathrm{H} 1$ as a substrate. Incubation with FSBA led to a time- and dose-dependent inactivation of CAK (Figure 1a, filled circles and squares). ATP blocked this action of FSBA (open circles and squares), indicating that CAK is indeed an ATP-binding protein.

To determine directly whether CAK possesses protein kinase activity, we examined whether CAK could phosphorylate a kinase-inactive mutant of $\mathrm{p} 33^{\mathrm{cdk} 2}$. The human $\mathrm{p}^{3} 3^{\mathrm{cdk} 2}$ and Xenopus $\mathrm{p} 34^{\mathrm{cdc} 2}$ proteins are $89 \%$ identical, so it was not surprising that CAK could activate $\mathrm{p} 33^{\mathrm{cdk} 2}$ in the presence of cyclin (Connell-Crowley et al., 1993). Mutation of a conserved asparagine in the catalytic

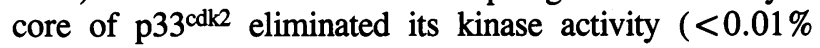
of wild type activity; Connell-Crowley et al., 1993). This mutant form of human $\mathrm{p}^{33^{\mathrm{cdk} 2}}$ was expressed in Escherichia coli and purified to homogeneity (ConnellCrowley et al., 1993). Phosphorylation of the N132A mutant of $\mathrm{p} 33^{\text {cdk2 }}$ occurred after incubation with highly purified CAK (Figure 1b) and was greatly stimulated by cyclin B (Figure 1b, compare lanes 8 and 7). Phosphorylation occurred on Thr160 since protein kinase activity toward Thr14 and Tyr15 was separated from CAK at the earliest stages of CAK purification (Solomon et al., 1992). The copurification of the most highly purified CAK with this kinase acting on $\mathrm{p}^{33^{\mathrm{cd} k 2}}$ (Figure 1c) indicates that the two represent the same activity.

\section{Purification of CAK}

CAK was purified by conventional means (see Table I) using the activation of $\mathrm{p} 34^{\mathrm{cdc} 2}$-cyclin B complexes as an assay. CAK activity was surprisingly stable during this purification. The initial purification of CAK through ammonium sulfate fractionation has already been described (Solomon et al., 1992). Briefly, highly concentrated extracts were prepared (Murray and Kirschner, 1989) from the eggs of 100 frogs that were arrested in interphase following destruction of the endogenous cyclins (Solomon et al., 1990). The extracts were diluted and clarified by ultracentrifugation prior to chromatography on DEAE-Sepharose. Peak fractions were pooled and CAK was precipitated with $38 \%\left(\mathrm{NH}_{4}\right)_{2} \mathrm{SO}_{4}$. Further fractionation on hydroxyapatite, Mono $Q$ and

a
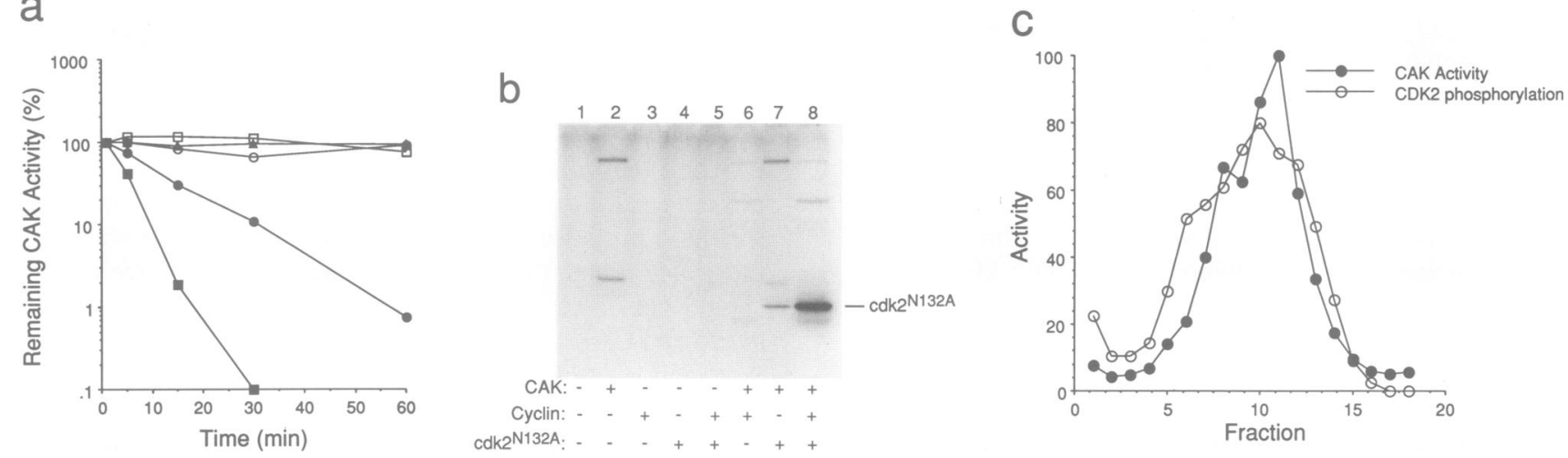

Fig. 1. CAK is a protein kinase. (a) Inactivation of CAK by FSBA. Ammonium sulfate-purified CAK was incubated in buffer alone (filled triangles), $0.2 \mathrm{mM}$ FSBA with (open circles) or without (filled circles) added $5 \mathrm{mM}$ ATP or $1 \mathrm{mM}$ FSBA with (open squares) or without (filled squares) added $5 \mathrm{mM}$ ATP, as indicated. The samples were diluted and the FSBA was inactivated by addition of DTT prior to assay of CAK activity. (b) CAK directly phosphorylates a kinase-deficient form of p33cdk2. Heparin-agarose-purified CAK (fraction 9), GT-cyclin and/or purified p33 $3^{\mathrm{cdk} 2}$ protein containing the N132A mutation were added to the indicated incubations in the presence of $\left[\gamma^{32}\right.$ P]ATP. The phosphorylated products were analyzed by gel electrophoresis and autoradiography. (c) Copurification of CAK activity and kinase activity toward p33cdk2. Fractions from the heparin-agarose column were assayed for CAK activity (same data as in Figure 2b; filled symbols) and for protein kinase activity toward the N132A mutant of human p33cdk2 (open symbols). Both activities were quantitated using a PhosphorImager and have been plotted on an arbitrary scale for comparison. 
heparin-agarose resulted in an overall purification of 13100 -fold with a yield of $8.9 \%$. The samples in Table I were assayed simultaneously, since quantitative CAK assays are somewhat imprecise and any given level of activity is probably only accurate to within a factor of two (see Materials and methods).

Potential protein components of CAK were examined by comparing the CAK activity profiles across part of the Mono $\mathrm{Q}$ column (Figure 2a) and across the heparin-agarose column (Figure $2 \mathrm{~b}$ ) with the Coomassie blue-stained gels of proteins in the same fractions. Major proteins of 41 and 36 $\mathrm{kDa}$ copurified with CAK activity. A minor copurifying protein of $43.5 \mathrm{kDa}$ (indicated by the arrow) could be seen in Figure $2 \mathrm{~b}$, just above the major $41 \mathrm{kDa}$ protein. This band may represent $\mathrm{p} 40^{\mathrm{MO} 15}$ (see below). Partial cDNA clones have been obtained for the $36 \mathrm{kDa}$ and the $41 \mathrm{kDa}$ proteins, using the PCR with degenerate oligonucleotide primers based on the sequences of tryptic fragments of the gel-purified proteins. The sequences of $\sim 50 \%$ of the $36 \mathrm{kDa}$ protein and $\sim 26 \%$ of the $41 \mathrm{kDa}$ protein have been determined by a combination of protein and DNA sequencing. None of the cloned sequences resembles any reported sequences.

\section{The relationship between CAK and p40M015}

Communication of preliminary experiments that were subsequently reported in one of the accompanying papers (Poon et al., 1993) suggested that CAK might be related to $\mathrm{p} 40^{\mathrm{MO}} \mathrm{15}$. The possibility that CAK contains proteins other than the 41 and $36 \mathrm{kDa}$ proteins was appealing for two reasons. First, neither the cloned 157 amino acids of the $36 \mathrm{kDa}$ protein nor 95 amino acids from sequenced tryptic peptides of the $41 \mathrm{kDa}$ protein showed similarity to any of the conserved motifs indicative of protein kinases (Hanks et al., 1988). Second, one of the tryptic peptides derived from a gel slice containing the $36 \mathrm{kDa}$ protein was identical over its nine residues to a portion of $\mathrm{p} 40^{\mathrm{MO}}$ (LKPNNLLLD, amino acids 157-165) although this peptide is derived from a highly conserved region in protein kinases (domain VI in Hanks et al., 1998).

To test the possibility that $\mathrm{p} 40^{\mathrm{MO}} \mathrm{is}$ was a component of

Table I. Purification of CAK

\begin{tabular}{lllllll}
\hline & Volume $(\mathrm{ml})$ & Total protein $(\mathrm{mg})$ & Specific activity (units/mg) & Total activity (units) & Fold purification & Yield (\%) \\
\hline Crude lysate & 1280 & 8840 & 828 & 3.98 & 35200 & 1 \\
DEAE & 1390 & 111 & 26.1 & 21600 & 6 & 100 \\
Ammonium sulfate & 22.5 & 10.6 & 147 & 16300 & 37 & 81 \\
Hydroxyapatite & 25.5 & 2.39 & 322 & 3410 & 46 & 9.7 \\
Mono Q & 2.20 & 0.06 & 52300 & 2620 & 276 \\
Heparin-agarose & 0.60 & & 3130 & 13100 & 8.9
\end{tabular}

CAK was purified as described in Materials and methods. A CAK concentration of 1 unit $/ \mathrm{ml}$ is defined as the amount required to activate $30 \%$ of the p34cdc2 in a standard activation reaction. The calculated yield from this particular assay at the hyroxyapatite step was low. More typically the one step yield from ammonium sulfate through hydroxyapatite was $\sim 50 \%$ with a $\sim 5$-fold increase in specific activity.
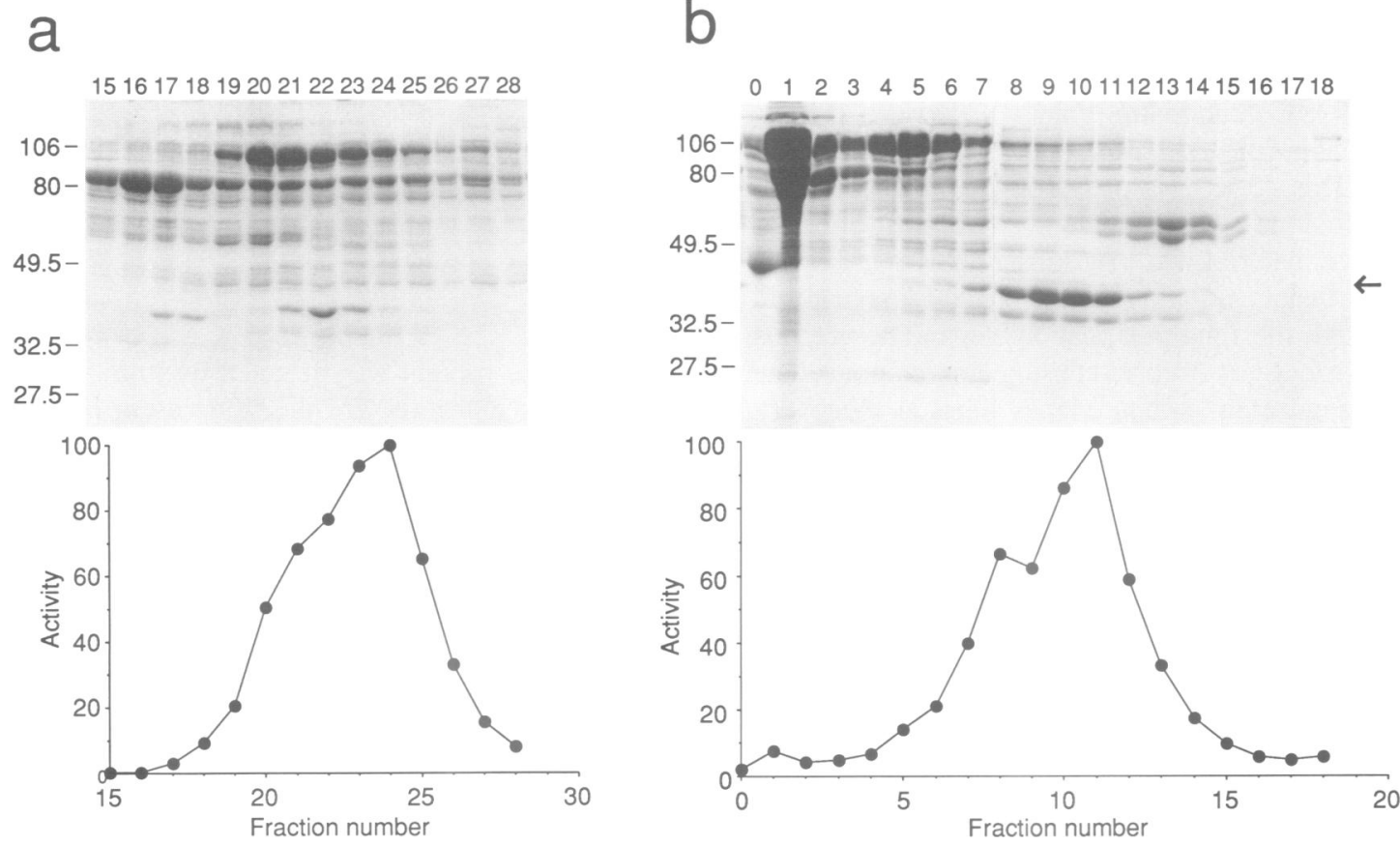

Fig. 2. Purification of CAK. Aliquots of fractions from a portion of the Mono $Q$ column (a) and from the heparin-agarose column (b) were assayed for CAK activity (graph) or electrophoresed and stained with Coomassie blue (photograph). Fraction 0 in panel $b$ indicates the flow-through material. The samples shown in panel $b$ were electrophoresed on two gels run simultaneously; the splice is located between fractions 7 and 8 . Sizes of pre-stained molecular weight markers (Bio-Rad) are indicated in $\mathrm{kDa}$. The arrow in panel $\mathrm{b}$ indicates a minor $43.5 \mathrm{kDa}$ protein, just above the major $41 \mathrm{kDa}$ protein, which might correspond to $\mathrm{p} 40^{\mathrm{MO}}$ 

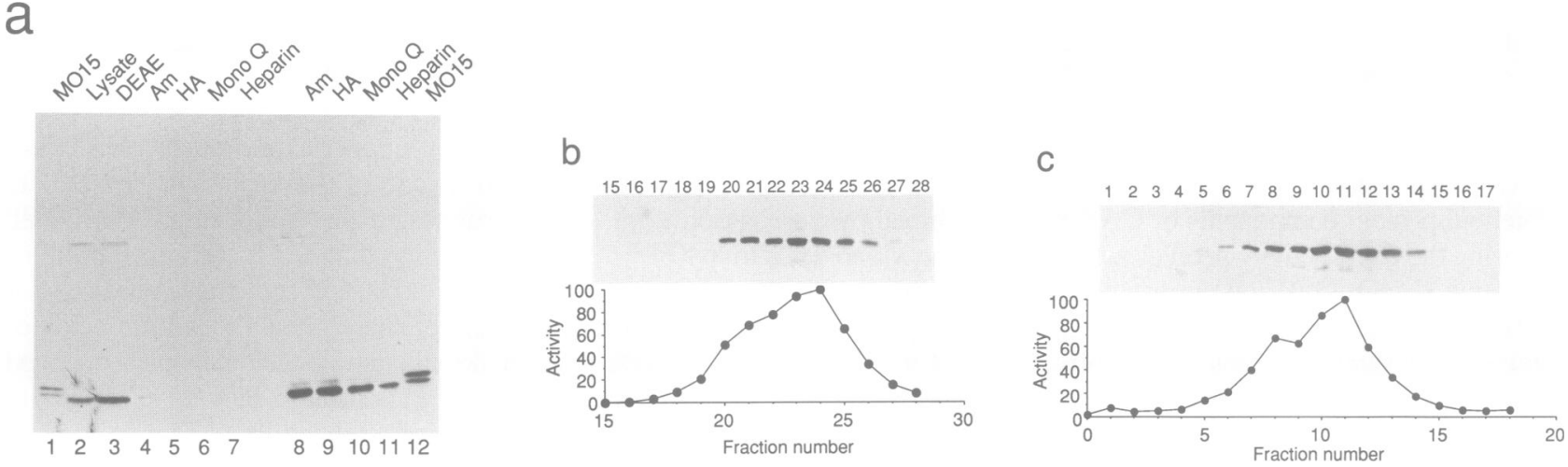

Fig. 3. Copurification of CAK and a p40MO15-like protein. (a) Anti-p40MO15 immunoblot of samples throughout the CAK purification. Aliquots containing $1 \mathrm{U}$ of CAK activity (lanes 2-7) from the crude lysate (lane 2) or after fractionation on DEAE (lane 3), ammonium sulfate (lane 4), hydroxyapatite (lane 5), Mono Q (lane 6) or heparin-agarose (lane 7), or $5 \mathrm{U}$ of CAK activity (lanes 8-11) after fractionation by ammonium sulfate (lane 8), hydroxyapatite (lane 9), Mono Q (lane 10) or heparin-agarose (lane 11) were electrophoresed and immunoblotted with an antiserum directed against the C-terminal one-third of $\mathrm{p} 40^{\mathrm{MO} O 15}$. Lanes 1 and 12 contained $0.5 \mu \mathrm{l}$ and $1.0 \mu \mathrm{l}$, respectively, of a reticulocyte lysate programmed with mRNA for $\mathrm{p} 40^{\mathrm{MO}} 15$; the lower band represents translational initiation at the authentic start site. (b) Aliquots from fractions 15-28 of the Mono $\mathrm{Q}$ column (lanes 1-14, respectively) were electrophoresed and immunoblotted with anti-p40MO15 antiserum. Shown below are the relative CAK activities of these fractions. (c) Aliquots from fractions 1-17 of the heparin-agarose column (lanes 1-17, respectively) were electrophoresed and immunoblotted with anti-p40 ${ }^{\mathrm{MO} 15}$ antiserum. Shown below are the relative CAK activities of these fractions.

CAK, we first determined whether it was present in highly purified fractions containing CAK activity (Figure 3a). Samples from each step of the purification were immunoblotted with an antiserum to $\mathrm{p} 40^{\mathrm{MO} 15}$ (lanes 2-11). Lanes 1 and 12 contained known amounts of in vitrotranslated $\mathrm{p} 40^{\mathrm{MO} 15}$ and served as size markers and as standards for quantitative estimates of abundance (see Discussion); the upper band of this doublet represents translational initiation at an ATG located 13 codons upstream of the authentic start site (Shuttleworth et al., 1990). Samples containing equal amounts of CAK activity from each purification step were analyzed in lanes 2-7 and samples containing five times as much activity were analyzed in lanes $8-11$. A major band of $43 \mathrm{kDa}$ was detected in all fractions, with a mobility almost identical to the lower band of the marker $\mathrm{p} 40^{\mathrm{MO} 15}$. Contaminating bands were seen only at early steps in the purification, even after extended exposures (not shown). This $43 \mathrm{kDa}$ is probably p $40^{\mathrm{MO} 15}$ itself.

Two conclusions were evident: (i) most of the immunoreactive material was lost during CAK purification and (ii) significant amounts of $\mathrm{p} 40^{\mathrm{MO} 15}$-like material persisted through the final purification steps. The greatest loss of immunoreactivity occurred during ammonium sulfate fractionation (Figure 3a, compare lanes 4 and 3). Recovery from this step onwards was high: comparison of the signal in lane 4 with the signal in lane 8 , which contained five times as much material, indicated that the amount of the p40 ${ }^{\mathrm{MO} 15}$-like protein present after heparin-agarose chromatography (Figure 3a, lane 11) was substantially $>20 \%$ (probably $\sim 50 \%$ ) of its level three steps earlier, after ammonium sulfate fractionation (Figure 3a, lane 8). From this and other immunoblots, we estimate that the $\mathrm{p} 40^{\mathrm{MO}}{ }^{5}$-like protein was enriched $\sim 1300$-fold during the $\sim 13000$-fold purification of CAK. This degree of copurification could be fortuitous or could indicate that a physically distinct subset $(\sim 10 \%)$ of this protein has CAK activity.

The relationship of this $\mathrm{p} 40^{\mathrm{MO}} 15$-like protein to CAK was further analyzed by comparing its distribution with that of CAK following chromatography on Mono $Q$ and heparin-agarose (Figure $3 \mathrm{~b}$ and $\mathrm{c}$, respectively). The

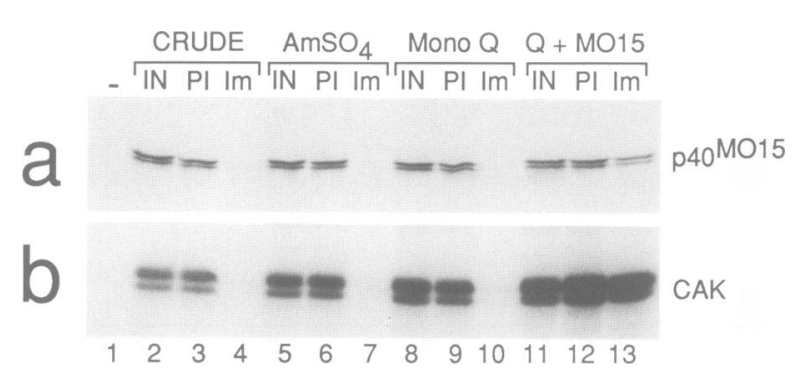

Fig. 4. Immunodepletion of CAK activity by an anti-p40MO15 antiserum. Equal amounts of CAK activity from the crude lysate (lanes 2-4), the ammonium sulfate step (lanes 5-7) or from the Mono $Q$ pool (lanes 8-13) were subject to immunoprecipitation. The input material (lanes 2, 5, 8 and 11), supernatant from a precipitation with preimmune serum (lanes 3, 6, 9 and 12), and supernatant from a precipitation with anti-p40MO15 antiserum (lanes 4, 7, 10 and 13) were assayed for CAK activity (b). (a) Shows the efficiency of precipitation of ${ }^{35} \mathrm{~S}-\mathrm{p} 40^{\mathrm{MO} 15}$ that had been added prior to immunoprecipitation. GST-MO15 was added to the samples in lanes 11-13 to compete specifically for $\mathrm{p} 40^{\mathrm{MO}} 15$ binding to the anti-p40 4015 antibodies. No CAK was added to the sample in lane 1.

p40 ${ }^{\mathrm{MO} 15}$-like protein was detected by immunoblotting; the CAK activity profiles are the same as in Figure 2. CAK activity and anti-p $40^{\mathrm{MO} 15}$ reactivity precisely coeluted. The partial proteolysis of this $\mathrm{p} 40^{\mathrm{MO}} \mathrm{I}_{\text {-like protein (Figure } 3 \mathrm{c} \text { ) }}$ could account for the presence of a p40 4015 -like peptide in the $36 \mathrm{kDa}$ region of the gel (see above).

Immunodepletion from crude lysates and extensively purified fractions was used to determine whether the copurifying $\mathrm{p} 40^{\mathrm{MO}} \mathrm{15}$-like protein could account for the observed CAK activity (Figure 4). Antibodies from the preimmune serum and from an anti-p40 $\mathrm{MO}^{\mathrm{M}}$ antiserum were prebound to protein $\mathrm{A}$-agarose beads prior to addition of diluted samples of crude lysate (lanes $2-4$ ), ammonium sulfate-purified CAK (lanes 5-7) or Mono Q-purified CAK (lanes 8-13). A trace amount of ${ }^{35} \mathrm{~S}$-labelled $\mathrm{p} 40^{\mathrm{MO} 15}$ from an in vitro translation reaction was added to each sample to monitor the efficiency of the immunodepletion (Figure 4a). The input samples (IN), supernatants from the preimmune depletion (PI) and supernatants from the immune 
depletion (Im) were assayed for CAK activity (Figure $4 \mathrm{~b}$ ). The preimmune serum failed to deplete any $\mathrm{p} 40^{\mathrm{MO} 15}$ or CAK activity from the three samples (compare lanes 3 and 2 , lanes 6 and 5, and lanes 9 and 8). In contrast, the anti$\mathrm{p} 40^{\mathrm{MO} 15}$ antiserum almost quantitatively depleted both the added ${ }^{35}$ S-labelled $\mathrm{p} 40^{\mathrm{MO}} 15$ and CAK (compare lanes 4 and 3 , lanes 7 and 6 , and lanes 10 and 9). Activation of $\mathrm{p} 34^{\mathrm{cdc} 2}$ was reduced to the background level seen in the complete absence of added CAK (Figure 4b, lane 1). A trace of $\mathrm{p} 40^{\mathrm{MO} 15}$ remained in the anti-p40 $\mathrm{MO}^{\mathrm{M}}$ supernatant from the crude lysate (see below). The ability of added $\mathrm{p} 40^{\mathrm{MO} 15}$ (as a fusion protein to glutathione S-transferase) to block the depletion of both Mono $\mathrm{Q}$ purified CAK and the added ${ }^{35} \mathrm{~S}$ labelled $\mathrm{p} 40^{\mathrm{MO} 15}$ verified the specificity of the anti-p $40^{\mathrm{MO} 15}$ antiserum (Figure 4, compare lanes 12 and 13 with lanes 9 and 10). Surprisingly, despite the quantitative and specific immunodepletion of the supernatants, only $\sim 5-10 \%$ of the input activity was recovered in the precipitates. This poor recovery was due to the inactivation of CAK by even protein A-purified IgG from this antiserum (data not shown).

It is significant that CAK could be immunodepleted from both crude and highly enriched fractions, rather than one or the other alone. Although simple immunodepletion from a crude lysate would also be consistent with a role for a p40 ${ }^{\mathrm{MO} 15}$-like protein as an activator of $\mathrm{CAK}$, such a function is excluded by immunodepletion from more purified fractions and by the copurification of $\mathrm{p} 40^{\mathrm{MO}} 15$ with $\mathrm{CAK}$ activity. Conversely, immunodepletion from only purified fractions would not necessarily indicate that this particular purified activity accounted for the bulk of the activity in crude samples; there could be multiple CAKs. Taken together, these results indicate that a p40 ${ }^{\mathrm{MO} 15}$-like protein is a component of CAK and accounts for essentially all of the CAK activity in Xenopus egg extracts.

We sought additional protein sequence data that could differentiate between $\mathrm{p} 40^{\mathrm{MO} 15}$ and a $\mathrm{p} 40^{\mathrm{MO}}$ - 5 -like protein. We reasoned that the $\mathrm{p} 40^{\mathrm{MO}} 15$-like protein was probably contained at a very low level in the gel slice of the $41 \mathrm{kDa}$ protein submitted for tryptic digestion and HPLC purification of peptides. The sizes of some of these peptides were determined by mass spectrometry. Three out of 14 informative peptides (with masses of 1678, 2941 and 3594) had sizes very close to predicted peptides from $\mathrm{p} 40^{\mathrm{MO}} 15$ (within $0.36 \%$, mean closest match for all 14 peptides $5.44 \%$, median closest match $3.77 \%$ ). These peptides were considered the best candidates for $\mathrm{p} 40^{\mathrm{MO}} 15$ peptides. The peptide with a $0.36 \%$ deviation from a predicted $\mathrm{p} 40^{\mathrm{MO}} 15$ tryptic peptide was sequenced and had a perfect $13 / 13$ match to amino acids $217-229$ of $\mathrm{p} 40^{\mathrm{MO}} 15$. We thus consider it very likely that the $\mathrm{p} 40^{\mathrm{MO}}$-like protein contained in CAK is actually $\mathrm{p} 40^{\mathrm{MO}} 15$.

\section{CAK activation of $p 33^{c d k 2}$}

The possibility that CAK is the physiological activator of other members of the $\mathrm{p} 34^{\mathrm{cdc} 2}$ family of protein kinases was tested using purified human $\mathrm{p} 33^{\mathrm{cdk} 2}$ protein as a substrate. Previous work indicated that CAK could activate $\mathrm{p} 33^{\mathrm{cdk} 2}$ in association with either an A- or a B-type cyclin (ConnellCrowley et al., 1993). These studies did not, however, address whether CAK was the only activator of $\mathrm{p} 33^{\mathrm{cdk} 2}$. There could, for instance, be two (or more) enzymes, e.g. 'CAK(cdc2)' and 'CAK(cdk2)', with strong preferences for one substrate, but weak overlapping specificity for the other. Fractions from all four chromatographic separations used
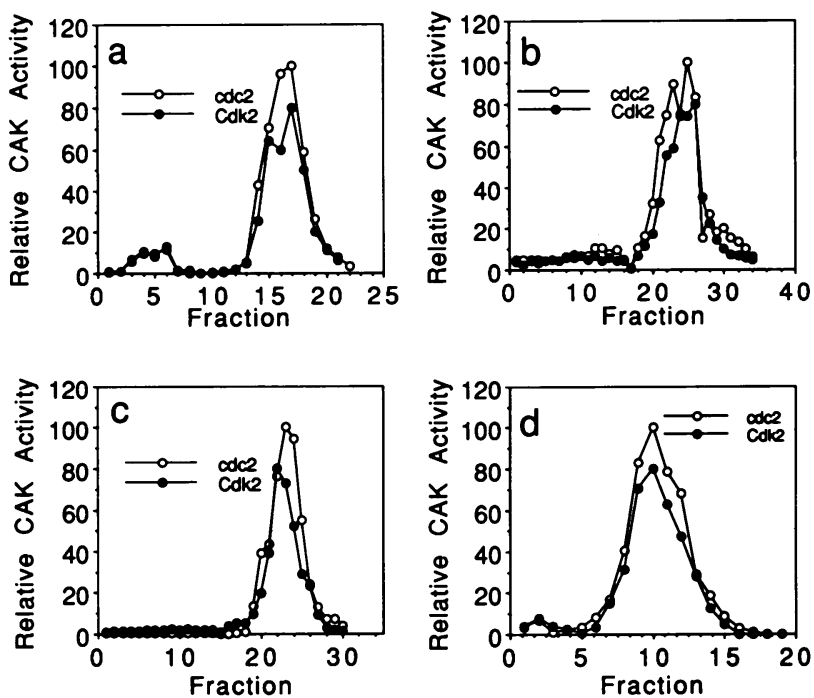

Fig. 5. Copurification of activating kinases for $\mathrm{p} 34^{\mathrm{cdc} 2}$ and for $\mathrm{p} 33^{\mathrm{cdk} 2}$. Fractions from the column chromatography steps in the purification of CAK were assayed for activating kinase activity toward either p34cdc2 (open circles) or p33cdk2 (filled circles) in the presence of cyclin B. Activity was quantitated using a PhosphorImager and has been plotted on an arbitrary scale for comparison. The column steps are DEAE-Sepharose (a), hydroxyapatite (b), Mono $Q$ (c) and heparin-agarose (d). Panels $c$ and $d$ represent re-assays of the samples used in Figure 2.

Table II. CAK activates both $\mathrm{p} 34^{\mathrm{cdc} 2}$ and $\mathrm{p} 33^{\mathrm{cdk} 2}$

\begin{tabular}{llll}
\hline & $\begin{array}{l}\text { CAK(cdc2) } \\
\text { (units/ml) }\end{array}$ & $\begin{array}{l}\text { CAK(Cdk2) } \\
\text { (units/ml) }\end{array}$ & Ratio $^{\mathrm{a}}$ \\
\hline Crude lysate & 27.4 & 19.3 & 1.42 \\
DEAE & 15.6 & 5.88 & 2.65 \\
Ammonium sulfate & 726 & 371 & 1.96 \\
Hydroxyapatite & 134 & 55.2 & 2.43 \\
Mono Q & 1195 & 601 & 1.99 \\
Heparin-agarose & 5227 & 3001 & 1.74 \\
\hline
\end{tabular}

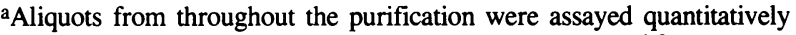
for their volume specific CAK activity using either p34cdc2 ['CAK(cdc2)'] or p33cdk2 ['CAK(Cdk2)'] as substrate in the presence of cyclin B. 'Ratio' indicates the ratio of 'CAK(cdc2)' activity to 'CAK(cdk2)' activity.

to purify CAK were re-assayed for their ability to activate complexes of cyclin B with either p34cdc2 (Figure 5, open circles) or $\mathrm{p} 33^{\mathrm{cdk} 2}$ (Figure 5, filled circles). 'CAK(cdc2)' and 'CAK(cdk2)' activities were superimposable in all respects including the partial flow-through of activity caused by overloading the DEAE column (Figure 5a). Slight variations in the patterns are insignificant; note, for instance, the small differences between these assays of ' $\mathrm{CAK}(\mathrm{cdc} 2)$ ' activity from the Mono $\mathrm{Q}$ (Figure $5 \mathrm{c}$ ) and heparin-agarose (Figure 5d) columns and the previous, independent assays of the identical column fractions (Figure 2a and b). If there are two CAKs in Xenopus egg extracts, they either have nearly identical physical properties, or 'CAK(cdk2)' remained bound to one of the columns after elution of 'CAK(cdc2)'.

As an independent test for the presence of a second CAKlike enzyme, we followed the specific activities of CAK toward both $\mathrm{p} 34^{\mathrm{cdc} 2}$ and $\mathrm{p} 33^{\mathrm{cdk} 2}$ at all purification stages (Table II). The ratio of these specific activities remained 
relatively constant over the course of the purification, with only some random variation. Given that loss of a 'CAK(cdk2)' by inactivation or strong binding to one of the columns would have increased this ratio dramatically, there appears to be only a single CAK protein.

A third test of whether a single CAK activated all p34 ${ }^{\mathrm{ddc2}}$. and $\mathrm{p} 33^{\mathrm{cdk} 2}$-containing complexes assessed the dependency of kinase activation on the presence of the $\mathrm{p} 40^{\mathrm{MO} O}$-like protein (Figure 6). Immunodepletion supernatants (from Figure 4) from Mono Q-purified CAK (Figure 6a) and from crude lysates (Figure 6b) were tested for their ability to activate complexes of $\mathrm{p} 34^{\mathrm{cdc} 2}$ and $\mathrm{p} 33^{\mathrm{cdk} 2}$ with either cyclin $A$ or cyclin B. Both cyclins were used in case the specificity of a p33 ${ }^{\mathrm{cdk} 2}$ activating kinase was influenced by the cyclin partner. Immunodepletion of $\mathrm{p} 40^{\mathrm{MO}} 15$-like proteins eliminated CAK activity toward all four complexes. For example, immunodepletion from Mono Q-purified CAK reduced CAK activity toward $\mathrm{p} 34^{\mathrm{cdc} 2}-$ cyclin A from control levels (Figure 6a, compare lane 4 with lanes 2 and 3 ) to the background level seen in the absence of CAK (Figure 6a, lane 1). The same pattern was observed using the other substrates, although the background activity (in the absence of CAK) of the $\mathrm{p}^{33^{\mathrm{cdk}} 2}$ - cyclin A complexes was higher (Figure 6a, lanes 9-12). Similarly, immunodepletion of $\mathrm{p} 40^{\mathrm{MO} O 15}$-like proteins from the crude lysate eliminated the bulk if not all of the specific activating kinase activity toward all four complexes (Figure 6b). It is difficult to conclude that all of the activity was depleted in this particular experiment since the background was higher (lanes 1, 5, 9 and 13) and since immunodepletion of $440^{\mathrm{MO} 15}$ from the crude lysate was incomplete (see above and Figure 4a, lane 4). Some background activation could also be due to the cyclin A-induced partial activation of $\mathrm{p} 33^{\mathrm{cdk} 2}$ in the absence of Thr 160 phosphorylation (Connell-Crowley et al., 1993).

These three approaches strongly argue that a single CAK protein, containing a protein identical or closely related to $\mathrm{p} 40^{\mathrm{MO}} \mathrm{15}$, controls the activation of the four possible complexes of $\mathrm{p} 34^{\mathrm{cdc2}}$ and $\mathrm{p} 33^{\mathrm{cdk} 2}$ with cyclin A and cyclin B. We have never seen evidence for a separate enzyme responsible for any significant fraction of the activating kinase activity toward one of these complexes.

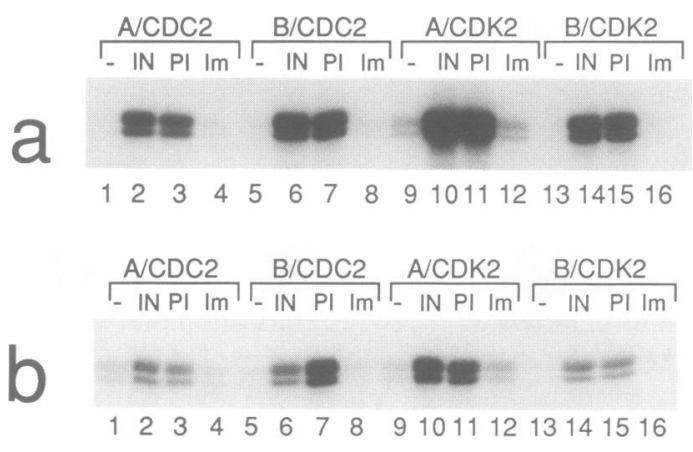

Fig. 6. A p40M015-like protein is required for activation of both $\mathrm{p} 34^{\mathrm{cdc} 2}$ and $\mathrm{p} 33^{\mathrm{cdk} 2}$ in the presence of either a type $A$ or type $B$ cyclin. p34cdc2 - cyclin A (lanes 1-4), p34cdc2-cyclin B (lanes 5-8), p33cdk2-cyclin A (lanes 9-12) and p33cdk2 - cyclin B (lanes 13-16) complexes were used as substrates for activation by the immunodepleted Mono Q-purified CAK samples (a) or the crude lysate samples (b) from Figure 4. No CAK (lanes 1, 5, 9 and 13), the input to the precipitations (lanes 2, 6, 10 and 14), the preimmune supernatants (lanes 3, 7, 11 and 15), and the anti-p40MO15 immune supernatants (lanes $4,8,12$ and 16) were assayed, respectively.

\section{Discussion}

CAK contains a protein identical or closely related to
p40M015

CAK was purified over 13000 -fold on the basis of its ability to activate cyclin $-\mathrm{p} 34^{\mathrm{cdc} 2}$ complexes, via phosphorylation of Thr161. Copurification of a $\mathrm{p} 40^{\mathrm{MO} O 15}$-like protein with CAK activity and immunodepletion of CAK with an antiserum to $\mathrm{p} 40^{\mathrm{MO} 15}$ demonstrate that CAK contains either $\mathrm{p} 40^{\mathrm{MO} 15}$ itself or a closely related protein. We have used highly enriched fractions to show that CAK is a protein kinase (see also below) and that this single enzyme is responsible for the bulk, if not all, of the activating phoshorylation of both $\mathrm{p}^{\mathrm{cdc} 2}$ and $\mathrm{p} 33^{\mathrm{cdk} 2}$ bound to either cyclin A or B in Xenopus egg extracts.

We believe that CAK actually contains $\mathrm{p} 40^{\mathrm{MO} 15}$, although neither our data nor that of others (Fesquet et al., 1993; Poon et al., 1993) can completely exclude the possibility that the detected component is actually a protein very closely related to $\mathrm{p} 40^{\mathrm{MO}}$. This component of CAK shares at least 22 amino acids with Xenopus $\mathrm{p} 40^{\mathrm{MO} 15}$ and cross-reacts with an antiserum to the C-terminal one-third of $\mathrm{p} 40^{\mathrm{MO}} 15$. In addition, only a single protein of the appropriate size was detected in immunoblots of crude lysate proteins; this protein is most likely p40MO15.

Among the many $\mathrm{p} 34^{\mathrm{cdc} 2}$-like protein kinases to which p $40^{\mathrm{MO} 15}$ is structurally similar, three stand out. A p34 ${ }^{\text {cdc2 }}$-like gene from rice encodes a protein that is $56 \%$ identical to p40 MO15 over 314 amino acids (Hata, 1991) and, as noted by Poon et al. (1993), a probable murine homolog has been identified (Ershler et al., 1993). In yeasts, the most similar sequence is the Saccharomyces cerevisiae KIN28 gene, which is $45 \%$ identical to $\mathrm{p} 40^{\mathrm{MO}}$ ov over 334 amino acids and is an essential gene (Simon et al., 1986). Despite the success of genetic approaches in identifying wee 1 and cdc25, which were eventually shown to be the protein kinase/phosphatase pair acting on Tyr15 of p34cdc2, there exist no strong candidates for CAK. Identification of a functional homolog of $\mathrm{p} 40^{\mathrm{MO}} \mathrm{15}$ in S.cerevisiae would set the stage for further genetic dissection of the role of CAK in the eukaryotic cell cycle.

\section{Xenopus CAK is rare}

Neither of the major proteins in 13100 -fold purified CAK is $\mathrm{p} 40^{\mathrm{MO} 15}$. First, the sizes of these proteins are 41 and 36 $\mathrm{kDa}$, whereas the size of the $\mathrm{p} 40^{\mathrm{MO}} \mathrm{15}$-like protein detected on immunoblots is $43 \mathrm{kDa}$. Intriguingly, a faint band at 43.5 $\mathrm{kDa}$ copurifies with CAK (Figure $2 \mathrm{~b}$ ) and may represent the $\mathrm{p} 40^{\mathrm{MO} 15}$-like protein (see also below). Second, the 41 $\mathrm{kDa}$ protein is too abundant to be the $\mathrm{p} 40^{\mathrm{MO} O 15}$-like protein detected by Western blotting (see below). Third, the sizes of all but an occasional tryptic fragment from the $41 \mathrm{kDa}$ protein (determined by mass spectrometry) were clearly different from the predicted tryptic fragments of $\mathrm{p} 40^{\mathrm{MO}} 15$ and the sequences of four tryptic fragments (encompassing 95 amino acids) of the $41 \mathrm{kDa}$ protein showed no similarity to $\mathrm{p} 40^{\mathrm{MO} 15}$. Fourth, the single $\mathrm{p} 40^{\mathrm{MO} 15}$-like peptide encountered while sequencing tryptic fragments of the 36 $\mathrm{kDa}$ protein is probably a contaminant caused by partial proteolysis of the $\mathrm{p} 40^{\mathrm{MO} 15}$-like protein. The extremely low sequencing yield of this peptide is consistent with this interpretation. The physiological relationship, if any, of the copurifying 41 and $36 \mathrm{kDa}$ proteins to CAK remains unclear. 
It is, however, startling that starfish CAK contains subunits of similar size, 37 and $40 \mathrm{kDa}$ (Fesquet et al., 1993)

Three independent methods were used to estimate the abundance of the $\mathrm{p} 40^{\mathrm{MO} 15}$-like protein in the purified fractions; the results are quite consistent, given their inherent imprecision. (i) The faint $43.5 \mathrm{kDa}$ protein indicated in Figure $2 b$ provides an upper estimate; this protein was present at $\sim 70 \mathrm{ng}$ per lane, or $3.5 \mathrm{ng} / \mu \mathrm{l}$ of each peak fraction. True $\mathrm{p} 40^{\mathrm{MO} 15}$ might be present at a lower, undetectable, level. (ii) Western blotting of purified fractions alongside a known amount of in vitro-translated $\mathrm{p} 40^{\mathrm{MO} 15}$ (Figure 3a) provided an independent estimate of $\sim 1 \mathrm{ng} / \mu \mathrm{l}$ in the heparin-agarose eluate. (iii) A minimum estimate is provided by the sequencing of a likely $\mathrm{p} 40^{\mathrm{MO} O 15}$-derived tryptic peptide (see Results) that was present at 2.2 pmol. Assuming a sequencing efficiency of $20 \%$ (average for all peptides was $10-14 \%$ ), the heparin-agarose eluate would contain at least $0.85 \mathrm{ng} / \mu \mathrm{l}$.

Given a $\mathrm{p} 40^{\mathrm{MO} 15}$ abundance of $2-3 \mathrm{ng} / \mu \mathrm{l}$, we estimate that purification of Xenopus CAK to homogeneity would require an overall $\sim 200-400 \times 10^{3}$-fold purification from the crude lysate (assuming a heterodimer; see below and Fesquet et al., 1993). The abundance of the p40 ${ }^{\mathrm{MO} 15}$-like protein in crude lysates, determined by Western blotting (Figure 3a) is $\sim 0.4 \mathrm{ng} / \mu \mathrm{l}$ or one part in $\sim 17000$. This number is in reasonable agreement with the above estimate since only a small subset of the p40MO15-like protein ( $\sim 5-10 \%)$ appears to copurify with CAK. Despite its low abundance, the high turnover number of CAK (see below) would allow it to activate larger amounts of p34cdc2 quite rapidly. It is remarkable that CAK is one to two orders of magnitude more abundant in starfish oocytes (Fesquet et al., 1993).

\section{CAK is an enzyme}

CAK has several properties expected of an enzyme. It has a $K_{m}$ for ATP of $\sim 40 \mu \mathrm{M}$, whereas its $K_{m}$ for p34 $4^{\mathrm{cdc} 2}$ is $>100 \mathrm{nM}$ (data not shown). For comparison, p34 cdc2 has a $K_{m}$ for ATP of $75 \mu \mathrm{M}$ and a $K_{m}$ for histone H1 of 2000 nM (Erikson and Maller, 1989). More importantly, CAK acts catalytically, rather than stoichiometrically. If the concentration of the $43.5 \mathrm{kDa}$ protein seen to copurify with CAK (Figure 2b) is taken as an upper limit, then each molecule of CAK can phosphorylate and activate at least 40 molecules of p34 ${ }^{\mathrm{cdc} 2}$ per min, or over 1200 catalytic events in a standard $30 \mathrm{~min}$ incubation (this work; Solomon et al., 1992; data not shown). For comparison, the turnover number of human $\mathrm{p} 33^{\mathrm{cdk} 2}$ is $\sim 106$ per min at saturating histone $\mathrm{H} 1$ concentration (from Connell-Crowley et al., 1993). The true turnover number for CAK is undoubtedly higher, since CAK may be less abundant and since these experiments were performed at $\mathrm{p} 34^{\mathrm{cdc} 2}$ concentrations well below the $K_{m}$ of CAK.

Since Thr161 aligns with an autophosphorylation site found in some protein kinases, it had been suspected that p34 cdc2-like proteins might also autophosphorylate (see for instance Nigg et al., 1991), making CAK an activator of autophosphorylation, rather than a protein kinase. This appears not to be the case. The sensitivity of CAK to FSBA (Figure 1a), and the copurification of CAK with a protein kinase activity (Figure 1c) and with a $440^{\mathrm{MO} 15}$-like protein (Figures $3 \mathrm{~b}, \mathrm{c}$ and 4 ), indicate that $\mathrm{CAK}$ is indeed a protein kinase. The $\mathrm{p} 33^{\mathrm{cdk} 2}$ mutant used here as a protein kinase substrate had $<0.01 \%$ of wild type activity (ConnellCrowley et al., 1993), a much lower residual level than could be demonstrated for a previously used substrate (Solomon et al., 1992).

It was also reported previously that CAK phosphorylated p34 ${ }^{\text {cdc2 }}$ in a strictly cyclin-dependent manner. In contrast, Poon et al. (1993) and this group observed phosphorylation of $\mathrm{p} 33^{\mathrm{cdk} 2}$ even in the absence of cyclin (Figure $1 \mathrm{~b}$ ). The greater sensitivity of the current assay and the use of p33 $3^{\mathrm{cdk} 2}$ instead of p34 $4^{\mathrm{cdc} 2}$ may have contributed to this difference. Alternatively, subtle misfolding of the bacterially expressed p33 $3^{\text {cdk2 }}$ may have afforded CAK access to Thr160, which it normally acquires only after cyclin binding to $\mathrm{p} 33^{\text {cdk2 }}$. Similar non-physiological phosphorylation of Tyr 15 on bacterially expressed $\mathrm{p} 34^{\mathrm{cdc} 2}$ by $\mathrm{pp} 60^{\mathrm{src}}$ has been observed (Gautier et al., 1991).

\section{CAK activation of other CDK proteins}

The sequence similarity between $\mathrm{p} 34^{\mathrm{cdc} 2}$ and $\mathrm{p} 33^{\mathrm{cdk} 2}$ suggested that CAK might phosphorylate and activate more than one protein kinase complex. Previous work demonstrated that CAK was capable of activating $p 33^{\text {cdk2 }}$ in the presence of either cyclin A or B (Connell-Crowley et al., 1993). Our current results indicate that CAK is responsible for the bulk of the activating kinase activity toward all four complexes of $\mathrm{p} 34^{\mathrm{cdc} 2}$ and $\mathrm{p} 33^{\mathrm{cdk} 2}$ with either cyclin A or cyclin B. It remains a remote possibility that 'CAK(cdc2)' and 'CAK(cdk2)', though different, precisely copurify and both contain $\mathrm{p} 40^{\mathrm{MO}} 15$-like proteins. CAK may phosphorylate additional members of the p34 ${ }^{\text {cdc2 }}$ family of protein kinases. CDK3, like p34 ${ }^{\mathrm{cdc} 2}$ and $\mathrm{p} 33^{\mathrm{cdk} 2}$, contains a YTHEVV motif surrounding the equivalent of Thr161 within a highly conserved region and is a likely target. An intriguing potential substrate is $\mathrm{p} 40^{\mathrm{MO} 15}$ itself, which contains YTHQVV at the equivalent position: perhaps CAK autoactivates. Other CDK proteins and more distantly related members of this protein kinase subfamily have diverged sequences surrounding this threonine (Meyerson et al., 1992) and may require different activating kinases. Some such complexes may even have a reduced or eliminated dependence on a CAK-like activator (Connell-Crowley et al., 1993). Like p34cdc2 (Meyerson et al., 1992), the cyclins (Xiong and Beach, 1991), cdc25 (Galaktionov and Beach, 1991) and wee1 (Lundgren et al., 1991), there may be a family of CAK-like enzymes, each containing a different $\mathrm{p} 40^{\mathrm{MO} 15}$-related protein.

We suggest that the name CAK be retained for this activity, despite the apparent expansion in its substrate specificity. As it is presently unknown whether CAK can activate all, or only a small subset, of the cyclin-dependent kinases, it would be misleading and possibly erroneous to change the name to one implying a far broader specificity. Moreover, if it becomes necessary, 'CAK' could encompass 'cdk activating kinase' or ' $\mathrm{p} 34^{\mathrm{cdc} 2}-\mathrm{p} 33^{\mathrm{cdk} 2}$ activating kinase', as well as 'p34cdc2 activating kinase'.

\section{Implications for the regulation of CAK}

There are a number of physical similarities between CAK and the $\mathrm{p} 34^{\mathrm{cdc} 2}$ family of protein kinases; these suggest that some aspects of CAK regulation may follow the p34 $4^{\text {cdc2 }}$ paradigm. Foremost is the $40 \%$ identity between $\mathrm{p} 40^{\mathrm{MO} 15}$ and human $\mathrm{p} 34^{\mathrm{cdc} 2}$ (Shuttleworth et al., 1990). The 
molecular size of CAK ( $200 \mathrm{kDa}$; Solomon et al., 1992; Fesquet et al., 1993; Poon et al., 1993) suggests that the $\mathrm{p} 40^{\mathrm{MO} 15}$-like protein in CAK may also have a binding partner. As with $\mathrm{p} 34^{\mathrm{cdc} 2}$, where only a subset of the protein is complexed with cyclin and active (Draetta and Beach, 1988), only a fraction of $\mathrm{p} 40^{\mathrm{MO} 15}$ appears to be associated with CAK activity. Indeed, purified starfish CAK contains two proteins, one of them a likely $\mathrm{p} 40^{\mathrm{MO} 15}$ homolog (Fesquet et al., 1993). Whether such a binding partner represents a true cyclin, or simply a required regulatory subunit, is not known. Despite these sequence and structural similarities, CAK has no histone $\mathrm{H} 1$ kinase activity and p34 ${ }^{\text {cdc2 }}$ has no CAK activity (Solomon et al., 1992).

CAK may also be subject to regulation by phosphorylation(s). As indicated above, p40 $\mathrm{MO} 15$ contains a threonine in a contex́t similar to that of Thr161 in p34 cdc2. If CAK does not autophosphorylate, there may well be a CAK activating kinase or CAKAK controlling CAK activation. $\mathrm{p} 40^{\mathrm{MO}} 15$ does not possess phosphorylatable residues at the equivalent of Thr14 and Tyr15 in p34 ${ }^{\mathrm{cdc} 2}$, and so is not subject to the same form of negative regulation. A key function of these phosphorylations in $\mathrm{p} 34^{\mathrm{cdc} 2}$ is to allow accumulation of inactive $\mathrm{p} 34^{\mathrm{cdc} 2}-$ cyclin complexes prior to their concerted activation at the $\mathrm{G}_{2} / \mathrm{M}$ transition (Solomon et al., 1990). Therefore, CAK may be activated gradually, as each molecule of the regulatory subunit binds, rather than abruptly, after a threshold concentration of inactive complexes has accumulated.

The essential nature of Thr161 phosphorylation in p34 ${ }^{\text {cdc2 }}$ activation makes CAK, the enzyme responsible for this phosphorylation, a likely target of regulation during the cell cycle. Thus far, CAK activity appears to be constant during early Xenopus development (Solomon et al., 1992). The temporal regulation of the enzymatic activity and substrate preferences of CAK (and CAK family enzymes) have not yet been examined in more complex cell cycles.

\section{Materials and methods}

\section{Buffers}

Protease inhibitors: $10 \mu \mathrm{g} / \mathrm{ml}$ each of leupeptin, chymostatin and pepstatin (purchased from Chemicon, Temecula, CA). EB: $15 \mathrm{mM} \mathrm{MgCl}_{2}, 20 \mathrm{mM}$ potassium EGTA, $10 \mathrm{mM}$ DTT, $80 \mathrm{mM}$ potassium $\beta$-glycerophosphate, pH 7.3 and protease inhibitors. Buffer D: $10 \mathrm{mM} \mathrm{NaCl}, 1 \mathrm{mM}$ DTT, $1 \mathrm{mM}$ $\mathrm{MgCl}_{2}, 0.1 \mathrm{mM}$ sodium EDTA, $20 \mathrm{mM}$ triethanolamine ( $\mathrm{pH} 8.0$ at $4^{\circ} \mathrm{C}$ ) and protease inhibitors. Buffer HA1: $1 \mathrm{mM} \mathrm{MgCl}_{2}, 1 \mathrm{mM}$ DTT, $20 \mathrm{mM}$ potassium-PIPES ( $\mathrm{pH} 6.8$ at $4^{\circ} \mathrm{C}$ ) and $0.1 \times$ protease inhibitors. Buffer HA2: $1 \mathrm{mM} \mathrm{MgCl} 2,1 \mathrm{mM}$ DTT, $1 \mathrm{M}$ potassium phosphate (pH 6.8 at $4^{\circ} \mathrm{C}$ ) and $0.1 \times$ protease inhibitors. Buffer $\mathrm{H}: 10 \mathrm{mM} \mathrm{NaCl}, 1 \mathrm{mM}$ $\mathrm{MgCl}_{2}, 0.1 \mathrm{mM}$ potassium EDTA, $20 \mathrm{mM}$ potassium-HEPES and protease inhibitors. SDS-PAGE sample buffer: $6.6 \%$ SDS, $26 \%(\mathrm{v} / \mathrm{v})$ glycerol, $100 \mathrm{mM}$ DTT, $262 \mathrm{mM}$ Tris base and bromophenol blue. TB: $25 \mathrm{mM}$ Tris base, $192 \mathrm{mM}$ glycine and $15 \%(\mathrm{v} / \mathrm{v})$ methanol. TBST: 154 $\mathrm{mM} \mathrm{NaCl}, 10 \mathrm{mM}$ Tris $-\mathrm{HCl}\left(\mathrm{pH} 8.0\right.$ at $\left.23^{\circ} \mathrm{C}\right)$ and $0.1 \%(\mathrm{v} / \mathrm{v})$ Tween 20. IP buffer: EB containing $1 \mathrm{mg} / \mathrm{ml}$ ovalbumin and $0.5 \% \mathrm{NP}-40$.

\section{Protein reagents}

Glutathione S-transferase-cyclin B (GT-cyclin or cyclin B), which contains an N-terminal fusion of the enzyme glutathione S-transferase (Smith and Johnson, 1988) to a sea urchin type B cyclin, was expressed in E.coli and affinity purified as previously described by Solomon et al. (1990). Xenopus p34cdc2 protein was expressed in reticulocyte lysates as previously described by Gautier et al. (1991). Human p33cdk2, the N132A mutant of p33cdk2, and human cyclin A were expressed in E.coli and purified as previously described by Connell-Crowley et al. (1993).

p40 ${ }^{\mathrm{MO} 15}$ was expressed in E.coli as a fusion protein with glutathione Stransferase (GST-MO15) and by in vitro translation of the cDNA in reticulocyte lysates. Construction of GST-MO15 has been described by Poon et al. (1993). The protein was induced as described but was purified according to Solomon et al. (1990). For in vitro transcription, an SP64T transcription vector containing the MO15 cDNA was linearized with EcoRI followed by transcription by SP6 polymerase. The mRNA was translated in $50 \mu \mathrm{l}$ of a reticulocyte lysate (Promega, Madison, WI) containing $90 \mu \mathrm{Ci}$ of $\left.{ }^{35} \mathrm{~S}\right]$ methionine (Amersham, Arlington Heights, IL), $40 \mu \mathrm{M}$ cold methionine, or both. TCA precipitation of incorporated $\left[{ }^{35} \mathrm{~S}\right]$ methionine indicated that $9.6 \mathrm{nM} \mathrm{p} 40^{\mathrm{MO} 15}$ at a specific activity of $6.1 \times 10^{4}$ c.p.m. $/ \mu \mathrm{l}$ was synthesized in the absence of added cold methionine and that $11 \mathrm{nM}$ $\mathrm{p} 40^{\mathrm{MO} 15}$ was synthesized in its presence.

\section{CAK assays}

The CAK assay is a modification of the one described previously by Solomon et al. (1992). Briefly, fractions to be assayed were incubated with Xenopus p34cdc2 and GT-cyclin, diluted and then this reaction was assayed for the histone $\mathrm{H} 1$ kinase activity of the activated p34cdc2. The use of less p34cdc2 in the initial incubation, coupled with a smaller dilution before the histone H1 kinase assay, increased the signal to noise ratio by reducing the low background of activation produced by reticulocyte lysate components in the absence of added CAK. A reaction mix was prepared consisting of $10 \mu \mathrm{l}$ of reticulocyte lysate programmed with mRNA for Xenopus $\mathrm{p} 34^{\mathrm{cdc} 2}(\sim 12$ $\left.\mathrm{ng} / \mu \mathrm{l} \mathrm{p} 34^{\mathrm{cdc} 2}\right), 2 \mu \mathrm{l}$ of GT-cyclin $(\sim 1.9 \mu \mathrm{M}), 2 \mu \mathrm{l}$ of $1 \mathrm{M} \mathrm{MgCl}_{2}, 2 \mu \mathrm{l}$ of $100 \mathrm{mM} \mathrm{ATP}$ and $84 \mu \mathrm{l}$ of EB containing $1 \mathrm{mg} / \mathrm{ml}$ ovalbumin. $5 \mu \mathrm{l}$ of a sample to be assayed for $\mathrm{CAK}$ activity were mixed with $5 \mu \mathrm{l}$ of this reaction mix and incubated at $23^{\circ} \mathrm{C}$. After $30 \mathrm{~min}, 40 \mu \mathrm{l}$ of EB containing $1 \mathrm{mg} / \mathrm{ml}$ ovalbumin were added and the sample was stored on ice or frozen in liquid nitrogen. For the histone $\mathrm{H} 1$ kinase assay, $10 \mu \mathrm{l}$ of the sample were added to $6 \mu \mathrm{l}$ of a kinase mix containing $0.25 \mu \mathrm{Ci} / \mu \mathrm{l}\left[\gamma^{-32} \mathrm{P}\right] \mathrm{ATP}, 0.267 \mathrm{mg} / \mathrm{ml}$ histone $\mathrm{H} 1$ [Boehringer Mannheim, Indianapolis, IN; stored in $0.2 \mathrm{M} \mathrm{NaCl}$, $1 \mathrm{mM}$ DTT, $0.1 \mathrm{mM}$ EDTA, $20 \mathrm{mM}$ Tris $-\mathrm{HCl}(\mathrm{pH} \mathrm{7.4)}$ and protease inhibitors] and $1 \mathrm{mM}$ ATP. The reaction was quenched after $15 \mathrm{~min}$ at $23^{\circ} \mathrm{C}$ by addition of $16 \mu \mathrm{l}$ of SDS-PAGE sample buffer. Samples were electrophoresed in $10 \%$ polyacrylamide gels and subjected to autoradiography.

CAK activation of human $\mathrm{p} 33^{\mathrm{cdk} 2}$ complexes (Figure 5) was performed similarly. The reaction mix contained the same components as above, except that the $10 \mu \mathrm{l}$ of $\mathrm{p} 34^{\mathrm{cdc} 2}$ were replaced with $3.3 \mu \mathrm{l}$ of $2.6 \mu \mathrm{M}$ p33 $3^{\mathrm{cdk} 2}$ protein purified from E.coli. GT-cyclin was replaced as necessary by an equal volume of $1.0 \mu \mathrm{M}$ human cyclin $\mathrm{A}$.

For quantitative $\mathrm{CAK}$ assays, the extent of histone $\mathrm{H} 1$ phosphorylation was determined by a PhosphorImager scan. A CAK concentration of 1 unit $/ \mathrm{ml}$ was defined as the concentration necessary to achieve $30 \%$ of the maximum possible activation of $\mathrm{p} 34^{\mathrm{cdc} 2}$ under the standard conditions using saturating levels of CAK. This level of activation is within the linear range of the assay (data not shown). To ensure consistency and that saturating activation was achieved, specific activities of samples to be compared (see Tables I and II) were always determined simultaneously by assaying dilution series of the samples of interest. Nevertheless, due to the two-step nature of the assay, and the necessity to interpolate from dilution series, there is considerable variability in this quantitative assay. On reassay, the specific activities of individual samples can vary as much as 2-fold.

Direct phosphorylation of the N132A mutant of $\mathrm{p} 33^{\mathrm{cdk} 2}$ was performed in a $16 \mu \mathrm{l}$ reaction containing $3 \mu \mathrm{l}$ of a 1:100 dilution of heparin-agarose purified CAK, $190 \mathrm{nM}$ p33cdk2, $120 \mathrm{nM}$ GT-cyclin, $50 \mu \mathrm{M}$ ATP and 6.25 $\mu \mathrm{Ci}\left[\gamma^{-32} \mathrm{P}\right] \mathrm{ATP}$ in EB containing $1 \mathrm{mg} / \mathrm{ml}$ ovalbumin. Any omitted component (see Figure 1b) was replaced with buffer. SDS-PAGE sample buffer was added after a $30 \mathrm{~min}$ incubation at $23^{\circ} \mathrm{C}$. For Figure 1c, the reaction contained $3 \mu \mathrm{l}$ of heparin-agarose purified CAK (1:100 dilution), $300 \mathrm{nM} \mathrm{p33cdk2}, 37 \mathrm{nM}$ GT - cyclin, $35 \mu \mathrm{M}$ ATP and $3.7 \mu \mathrm{Ci}\left[\gamma^{-32}\right.$ P]ATP in a $10 \mu \mathrm{l}$ reaction.

\section{Purification of CAK}

The eggs from 100 frogs were collected and extracts arrested in interphase were prepared as described by Solomon $e t$ al. (1990). Approximately 120 $\mathrm{ml}$ of crude extract was obtained and stored at $-80^{\circ} \mathrm{C}$ until use. Approximately $30 \mathrm{ml}$ of extract were thawed in an $\sim 30^{\circ} \mathrm{C}$ water bath and diluted with $9 \mathrm{vol}$ of buffer $\mathrm{D}$ containing $50 \mathrm{mM} \mathrm{NaCl}$ and $2 \times$ protease inhibitors and centrifuged at 55000 r.p.m. for $45 \mathrm{~min}$ in the $60 \mathrm{Ti}$ rotor. The supernatant was loaded at $80 \mathrm{ml} / \mathrm{h}$ onto $200 \mathrm{ml}$ of DEAE-Sepharose FF (Sigma, St Louis, MO) equilibrated in buffer D without protease inhibitors in a $2.5 \mathrm{~cm}$ diameter column. The column was washed with $450 \mathrm{ml}$ of buffer D containing $50 \mathrm{mM} \mathrm{NaCl}$ and proteins were eluted with a $750 \mathrm{ml}$ linear gradient from the same buffer to buffer D containing $300 \mathrm{mM} \mathrm{NaCl}$. Ten millilitre fractions were collected from the beginning of the gradient at a flow rate of $80 \mathrm{ml} / \mathrm{h}$. CAK activity was assayed in undiluted samples and typically peaked in fractions $38-74(94-142 \mathrm{mM} \mathrm{NaCl}$ as determined by conductivity measurements). These fractions were pooled and solid $\left(\mathrm{NH}_{4}\right)_{2} \mathrm{SO}_{4}$ was added to $38 \%$. (Fractionation with $\left(\mathrm{NH}_{4}\right)_{2} \mathrm{SO}_{4}$ was much 
sharper when performed after DEAE chromatography, rather than as the first step in the purification.) The precipitate was collected by centrifugation at 20000 r.p.m. for $20 \mathrm{~min}$ in the $35 \mathrm{Ti}$ rotor. The pellets were rinsed once in buffer $\mathrm{D}$ containing $50 \mathrm{mM} \mathrm{NaCl}$ and $38 \%\left(\mathrm{NH}_{4}\right)_{2} \mathrm{SO}_{4}$, resuspended in buffer $\mathrm{D}$ containing $50 \mathrm{mM} \mathrm{NaCl}$ and dialyzed against 2 1 of buffer $\mathrm{D}$ containing $50 \mathrm{mM} \mathrm{NaCl}$ and $0.1 \times$ protease inhibitors overnight. The precipitate that formed was removed by centrifugation at 10000 r.p.m. for $10 \mathrm{~min}$ in the HB-4 rotor. Samples were quick frozen in liquid nitrogen and stored at $-80^{\circ} \mathrm{C}$ until needed.

The ammonium sulfate fractions from four DEAE column runs were pooled and centrifuged at 50000 r.p.m. for $10 \mathrm{~min}$ in the $60 \mathrm{Ti}$ rotor prior to application onto a TSK hydroxyapatite column $(7.5 \mathrm{~mm} \times 7.5 \mathrm{~cm}$; HA-1000, TosoHaas, Philadelphia, PA) using FPLC (Pharmacia). The column was equilibrated in buffer $\mathrm{HAl}$ and run at $1 \mathrm{ml} / \mathrm{min} .2 .8 \mathrm{ml}$ of sample was applied using a $3 \mathrm{ml}$ loop followed by $5 \mathrm{ml}$ of buffer HA1. A $20 \mathrm{ml}$ gradient was applied beginning at $95 \%$ buffer $\mathrm{HA1}-5 \%$ buffer HA2 and ending at $80 \%$ buffer HA1-20\% buffer HA2. $1 \mathrm{ml}$ fractions were collected beginning at the time of sample application. Seven sequential runs were collected into the same tubes. CAK assays were performed on samples diluted 200 -fold into EB containing $1 \mathrm{mg} / \mathrm{ml}$ ovalbumin. Fractions 22-24 were pooled and dialyzed overnight against 21 of buffer $D$ containing $0.1 \times$ protease inhibitors.

The entire sample $(25.5 \mathrm{ml})$ was applied onto a $1 \mathrm{ml}$ Mono $\mathrm{Q}$ column (Pharmacia, Pleasant Hill, CA) equilibrated in buffer D containing $20 \mathrm{mM}$ $\mathrm{NaCl}$. The column was rinsed with $2 \mathrm{ml}$ of the same buffer and a $20 \mathrm{ml}$ gradient was applied from buffer D containing $150 \mathrm{mM} \mathrm{NaCl}$ to buffer D containing $350 \mathrm{mM} \mathrm{NaCl}$. The column was run at $1 \mathrm{ml} / \mathrm{min}$ and 0.5 $\mathrm{ml}$ fractions were collected beginning with the $2 \mathrm{ml}$ rinse. Aliquots were diluted 3600 -fold into EB containing $1 \mathrm{mg} / \mathrm{ml}$ ovalbumin for assay of CAK activity and $20 \mu \mathrm{l}$ aliquots were added to $20 \mu \mathrm{l}$ of protein gel sample buffer for SDS-PAGE analysis. Fractions 20-24 were pooled and dialyzed against 11 of buffer $\mathrm{H}$ containing $0.1 \times$ protease inhibitors.

The Mono $Q$ peak of CAK activity was then applied onto a $0.25 \mathrm{ml}$ heparin-agarose column (CNBr linkage, $4 \%$ beaded agarose, Sigma) in a $1 \mathrm{ml}$ syringe barrel equilibrated in buffer $\mathrm{H}$. Samples were eluted by a manually applied stepwise gradient. Gradient steps contained $0.5 \mathrm{ml}$ of buffer $\mathrm{H}$ followed by $0.1 \mathrm{ml}$ of buffer $\mathrm{H}$ containing $180 \mathrm{mM} \mathrm{NaCl}, 0.1 \mathrm{ml}$ of buffer $\mathrm{H}$ containing $200 \mathrm{mM} \mathrm{NaCl}$ through $0.1 \mathrm{ml}$ of buffer $\mathrm{H}$ containing $480 \mathrm{mM} \mathrm{NaCl}$ and $0.5 \mathrm{ml}$ of buffer $\mathrm{H}$ containing $500 \mathrm{mM} \mathrm{NaCl}$. Fractions of the same sizes were collected manually. Fraction 0 corresponds to the flow-through material, fraction 1 corresponds to material eluted upon application of buffer $\mathrm{H}$ containing $160 \mathrm{mM} \mathrm{NaCl}$ and fraction 18 corresponds to the material eluted by buffer $\mathrm{H}$ containing $500 \mathrm{mM} \mathrm{NaCl}$. Fractions were diluted 10000 -fold for CAK assays. For protein analysis, $1 \mu \mathrm{l}$ of $2 \%(\mathrm{w} / \mathrm{v})$ deoxycholate and $10 \mu \mathrm{l}$ of $100 \%$ (w/v) TCA were added to $88 \mu \mathrm{l}$ of each fraction. After incubation for $30 \mathrm{~min}$ at $4^{\circ} \mathrm{C}$, protein precipitates were collected by centrifugation at 14000 r.p.m. in an Eppendorf microfuge for $10 \mathrm{~min}$ at $23^{\circ} \mathrm{C}$. The pellets were resuspended in $20 \mu \mathrm{l}$ of SDS-PAGE sample buffer containing an extra $0.1 \mathrm{M}$ Tris. $4 \mu \mathrm{l}$ of each precipitated fraction were diluted with $20 \mu \mathrm{l}$ of $0.5 \times$ SDS-PAGE sample buffer, run on a $10 \%$ polyacrylamide gel and stained with Coomassie Blue. The remaining material from the peak of CAK activity (fractions 8-13) was pooled and electrophoresed on two lanes of a $10 \%$ polyacrylamide gel. After brief staining and destaining, bands were excised and submitted for protein sequencing of HPLC-purified tryptic fragments by the W.M.Keck Foundation Biotechnology Resource Laboratory (Yale University).

Protein concentrations through the Mono $\mathrm{Q}$ column were determined using the Bradford reagent with BSA as a standard. The protein concentration of the heparin-agarose eluate was determined in two ways: (i) the amount of Coomassie blue stainable protein on the gel in Figure $2 b$ was estimated by comparison to known amounts of BSA and (ii) the amount of the 41 $\mathrm{kDa}$ protein was determined by amino acid analysis and the total protein in the fractions was assumed to be twice as much. The yield of CAK activity through the purification was $8.9 \%$. This yield would have been $\sim 12.5 \%$ if significant aliquots had not been retained at most steps.

\section{5'-p-fluorosulfonylbenzoyladenosine inactivation of CAK}

For the time course of FSBA (Sigma) inactivation of CAK, $2 \mu \mathrm{l}$ of ammonium sulfate-purified CAK were diluted with $18 \mu \mathrm{l}$ of $50 \mathrm{mM} \mathrm{NaCl}$, $10 \mathrm{mM} \mathrm{MgCl} 2,1 \mathrm{mg} / \mathrm{ml}$ ovalbumin, $10 \%$ DMSO and $50 \mathrm{mM}$ potassium-HEPES. Where appropriate, $2 \mu \mathrm{l}$ of $100 \mathrm{mM}$ ATP were added. Two microlitres of DMSO containing $0,2 \mathrm{mM}$ or $10 \mathrm{mM}$ FSBA were added at $0 \mathrm{~min}$. At appropriate times, $2 \mu \mathrm{l}$ were removed and the FSBA was quenched by dilution into $40 \mu \mathrm{l}$ of EB containing $1 \mathrm{mg} / \mathrm{ml}$ ovalbumin prior to determination of CAK activity. CAK activity was quantitated by Cerenkov counting of excised bands.

\section{Immunological methods}

Gels for electrophoretic transfer were incubated in TB for $15 \mathrm{~min}$. Proteins were transferred to Immobilon P membranes (Millipore, Bedford, MA) at $54 \mathrm{~V}(\sim 420 \mathrm{~mA})$ for $3 \mathrm{~h}$ in the Hoeffer (San Francisco, CA) model TE42 Transphor unit. Molecular weight markers were visualized by staining with Ponceau S (Sigma). The membranes were blocked by incubation for $1 \mathrm{~h}$ in TBST containing 5\% non-fat dry milk and incubated overnight with a 1:500 dilution of anti-p40 4015 antiserum (15SSRV, directed against the C-terminal 122 amino acids of $\mathrm{p} 40^{\mathrm{MO} O 15}$; Shuttleworth et al., 1990) in the same buffer. The filter was rinsed once in the same buffer and then four times for at least 15 min each in TBST. Incubation with an HRP-linked donkey anti-rabbit secondary antibody (Amersham) was performed at a 1:1000 or a $1: 10000$ dilution into TBST containing $5 \%$ non-fat dry milk. After a $1 \mathrm{~h}$ incubation, the filter was washed as above. Detection was by chemiluminescence using the ECL reagents (Amersham).

For immunoprecipitation, 1.0 units of CAK from different stages in the purification was diluted into $200 \mu \mathrm{l}$ of IP buffer containing $1.0 \mu \mathrm{l}$ of reticulocyte lysate that had been programmed with mRNA for $\mathrm{p} 40^{\mathrm{MO}} 15(\sim 9.6 \mathrm{nM}$ p40MO15, specific activity of $6.1 \times 10^{4}$ c.p.m. [ $\left.\left.{ }^{35} \mathrm{~S}\right] \mathrm{p} 40^{\mathrm{MO}} \mathrm{15} / \mu \mathrm{l}\right)$. For each precipitation, $15 \mu \mathrm{l}$ of protein A-agarose beads were washed with IP buffer, incubated in IP buffer with $5 \mu$ l of immune or preimmune antiserum for $1 \mathrm{~h}$ with rotation to pre-bind the IgG, washed with IP buffer and incubated with the sample for immunoprecipitation. Preliminary experiments indicated that $5 \mu \mathrm{l}$ of antiserum was the minimum necessary for quantitative immunodepletion under these conditions. After $1 \mathrm{~h}$ with rotation, the beads were pelleted, washed 2-4 times in IP buffer and resuspended in $200 \mu$ l of IP buffer. $5 \mu$ l aliquots were removed for CAK assay and $10 \mu \mathrm{l}$ aliquots were removed for electrophoretic/autoradiographic analysis of the efficiency of immunoprecipitation. Addition of $\sim 0.3 \mu \mathrm{g}$ GST-MO15 was used to block specific precipitation in some samples.

\section{Acknowledgements}

M.S. is extremely indebted to Tim Hunt for catalyzing the collaboration reported here. M.S. is also grateful to Tim Hunt and to J.S. for communication of early and intriguing results, to Jean-Claude Cavadore for exchanges of data before publication and to Marc Kirschner for his enthusiastic support and encouragement at the outset of this project. Essential technical and logistical advice was received from Ray Deshaies, Sankar Ghosh, David Gonda, Vic Myer and Sandra Wolin, and we thank Ray Deshaies, Deborah Enke, David Gonda, Jennifer Holmes and Geoffrey Laff for comments on the manuscript. We thank Joan Steitz and her lab for access to and training on an FPLC and a PhosphorImager, the W.M.Keck Foundation Biotechnology Resource Laboratory (Yale University) for their expert protein sequencing and advice, and John Flory and his staff for oligonucleotide synthesis. Joyce Wall provided invaluable technical support throughout. M.S. was supported by an Argall L. and Anna G.Hull Cancer Research Award and by an Andrew Mellon Fellowship, and J.W.H. was supported by an American Cancer Society Junior Faculty Award. This work was supported in whole, or in part, by the BRSG Grant RR05358 awarded by the Biomedical Research Support Grant Program, Division of Research Resources, National Institutes of Health (M.S.), the Wellcome Trust (J.S.), grants 1-RO1-GM47830 (M.S.) and 1-RO1-AG11085 (J.W.H.) from the NIH, The Robert A.Welch Foundation (Q-1279 to J.W.H.), and was aided by Basil O'Connor Starter Scholar Research Award No. 5-FY92-1153 from the March of Dimes Birth Defects Foundation (M.S.).

\section{References}

Coleman,R.F. (1983) Ann. Rev. Biochem., 52, 67-91.

Connell-Crowley,L., Solomon,M.J., Wei,N. and Harper,J.W. (1993) Mol. Biol. Cell, 4, 79-92.

Desai,D., Gu,Y. and Morgan,D.O. (1992) Mol. Biol. Cell, 3, 571-582. Draetta,G. and Beach,D. (1988) Cell, 54, 17-26.

Dunphy,W.G. and Kumagai,A. (1991) Cell, 67, 189-196.

Elledge,S.J. and Spottswood,M.R. (1991) EMBO J., 10, 2653-2659.

Erikson,E. and Maller,J.L. (1989) J. Biol. Chem., 264, 19577-19582.

Ershler,M.A., Nagorskaya,T.V., Visser,J.W.M. and Belyavsky,A.V. (1993) Gene, 124, 305-306.

Fesquet,D. et al. (1993) EMBO J., 12, 3111-3121.

Gabrielli,B.G., Lee,M.S., Walker,D.H., Piwnica-Worms,H. and Maller,J.L. (1992) J. Biol. Chem., 267, 18040-18046.

Galaktionov,K. and Beach,D. (1991) Cell, 67, 1181-1194.

Gautier,J., Solomon,M.J., Booher,R.N., Bazan,J.F. and Kirschner,M.W. (1991) Cell, 67, 197-211.

Gould,K.L. and Nurse,P. (1989) Nature, 342, 39-45. 
Gould,K.L., Moreno,S., Owen,D.J., Sazer,S. and Nurse,P. (1991) EMBO J., 10, 3297-3309.

Gu,Y., Rosenblatt,J. and Morgan,D.O. (1992) EMBO J., 11, 3995-4005. Hanks,S.K., Quinn,A.M. and Hunter,T. (1988) Science, 241, 42-53.

Hata,S. (1991) FEBS Lett., 279, 149-152.

Krek,W. and Nigg,E.A. (1991) EMBO J., 10, 305-316.

Lee,M.S., Ogg,S., Xu,M., Parker,L.L., Donoghue,D.J., Maller,J.L. and Piwnica-Worms,H. (1992) Mol. Biol. Cell., 3, 73-84.

Lundgren,K., Walworth,N., Booher,R., Dembski,M., Kirschner,M. and Beach,D. (1991) Cell, 64, 1111-1122.

McGowan,C.H. and Russell,P. (1993) EMBO J., 12, 75-85.

Meijer,L., Azzi,L. and Wang,J.Y. (1991) EMBO J., 10, 1545-1554.

Meyerson,M., Enders,G.H., Wu,C.-L., Su,L.-K., Gorka,C., Nelson,C., Harlow,E. and Tsai,L.-H. (1992) EMBO J., 11, 2909-2917.

Millar,J.B.A., McGowan,C.H., Lenaers,G., Jones, R. and Russell,P. (1991) EMBO J., 10, 4301-4309.

Murray,A.W. and Kirschner,M.W. (1989) Nature, 339, 275-280.

Nigg,E.A., Krek,W. and Peter,M. (1991) Cold Spring Harbor Symp. Quant. Biol., 56, 539-547.

Norbury,C. and Nurse,P. (1992) Annu. Rev. Biochem., 61, 441-470.

Norbury,C., Blow,J. and Nurse,P. (1991) EMBO J., 10, 3321-3329.

Nurse,P. (1990) Nature, 344, 503-508.

Paris,J., LeGuellec,R., Couturier,A., LeGuellec,K., Omilli,F., Camonis,J., MacNeill,S. and Philippe,M. (1991) Proc. Natl Acad. Sci. USA, 88, 1039-1043.

Parker,L.L. and Piwnica-Worms,H. (1992) Science, 257, 1955-1957.

Parker,L.L., Atherton-Fraser,S., Lee,M.S., Ogg,S., Falk,J.L., Swenson,K.I. and Piwnica-Worms,H. (1991) EMBO J., 10, 1255-1263.

Parker,L.L., Atherton-Fraser,S. and Piwnica-Worms,H. (1992) Proc. Natl Acad. Sci. USA, 89, 2917-2921.

Poon,R.Y.C., Yamashita,K., Adamczewski,J., Hunt,T. and Shuttleworth,J. (1993) EMBO J., 12, 3123-3132.

Shuttleworth,J., Godfrey,R. and Coleman,A. (1990) EMBO J., 9, 3233-3240.

Simon,M., Seraphin,B. and Faye,G. (1986) EMBO J., 5, 2697-2701.

Smith,D.B. and Johnson,K.S. (1988) Gene, 67, 31-40.

Solomon,M.J. (1993) Curr. Opin. Cell Biol., 5, 180-186.

Solomon,M.J., Glotzer,M., Lee,T.H., Philippe,M. and Kirschner,M.W. (1990) Cell, 63, 1013-1024.

Solomon,M.J., Lee,T. and Kirschner,M.W. (1992) Mol. Biol. Cell, 3, 13-27.

Strausfeld,U., Labbé,J.C., Fesquet,D., Cavadore,J.C., Picard,A., Sadhu,K., Russell,P. and Dorée,M. (1991) Nature, 351, 242-245.

Xiong,Y. and Beach,D. (1991) Curr. Biol., 1, 362-364.

Zoller,M.J., Nelson,N.C. and Taylor,S.S. (1981) J. Biol. Chem., 256, 10837-10842.

Received on April 27, 1993 